\title{
Determinants of becoming a zombie firm: A Pitch
}

\author{
Ondřej Machek ${ }^{\mathrm{a} 1}$ \\ ${ }^{\text {a }}$ Faculty of Business Administration, University of Economics, Prague
}

\begin{abstract}
This letter uses Faff's (2015) pitching research template to present a potential topic for research focused on "zombie firms" which consistently report negative equity or are unable to meet their interest payments, yet are still alive. The main research question is "What are the determinants of becoming a zombie firm?" The use of pitching research template was inspired by prof. Faff's lecture presented at the University of Economics, Prague in 2016. Besides developing the research idea, the paper presents the author's reflections on the process of preparing a research project with the help of the pitching template.
\end{abstract}

Keywords: Pitching research, zombie firms, negative equity

JEL codes: M10, L22

\section{Introduction}

When preparing a research project or a Ph.D. dissertation, it is essential to identify gaps in the current academic literature, to have a good idea about the methodology and data that will be used, and to clearly articulate the contribution of the research. Faff $(2015 ; 2017)$ presented a tool which can greatly facilitate this process. The pitching template is a "simple and systematic approach", which can be used for organizing research ideas (Faff, 2015). As such, it is very suitable for presentation of research projects, but at the same time, it can help a researcher sort his thoughts. Other possible applications include learning and development of research skills, or research collaboration, among others (see Faff, 2017 for a complete list of possible applications).

${ }^{1}$ Corresponding author: Faculty of Business Administration, University of Economics, Prague; nam. W. Churchilla 4, 13067 Prague; tel. (+420) 22409 8625; email address: ondrej.machek@vse.cz 
This letter presents the author's personal experience in using the pitching template to prepare a framework for a research project on zombie firms. The pitch can be considered to be "real" since the author, together with the colleagues from his university department, plans to carry out a research project focused on zombie firms. "Zombie firms" is a term which describes firms that should go out of the market or be forced to restructure radically, but they are still alive and operate normally. Other popular definitions define zombie firms as "firms which only generate enough cash to pay off the interest on their debt and not the debt itself" (Bridge, 2013). OECD describes zombie firms as "old firms that have persistent problems meeting their interest payments" (McGowan et al., 2017). These firms receive various subsidies and loans from governments and somehow manage to survive.

Zombie firms received some academic attention (Caballero et al., 2008; McGowan et al., 2017; Storz et al., 2017) as well as popular (Bridge, 2013; Stepek, 2008; Stothard \& Giles, 2012) attention. Most papers focused on zombie firms in Asian countries (such as Caballero et al., 2008), leaving European economies somehow apart, with only a few exceptions (for instance, the working paper of Storz et al. 2017). At the same time, zombie firms in Europe are a topic that certainly deserves attention. For instance, Stathard and Giles (2012) estimate that one in 10 British businesses are zombie firms, and Bridge (2013) claims that there are more than 100,000 zombie firms in the UK that are dragging the economy down.

Inspired by the literature focused on financial distress prediction, we are particularly interested in the factors that determine whether a firm becomes a "living death" or not.

The rest of the letter is organized as follows. First, we present a brief commentary on the application of the pitching template. The subsequent section describes personal reflections on the pitch exercise. Finally, concluding remarks are presented.

\section{Brief commentary on the application of the Pitching Template}

Table 1 displays the pitching template. The main research question reads: "What are the determinants of becoming a zombie firm?" The most recent key paper was published in 2017, the other two key papers were published before 2010. This is due to the fact that although there are several relevant and recent papers focusing on zombie firms, they have either not been published in top-tier journals (such as Urionabarrenetxea et al., 2016) or they have been published as working papers (Storz et al., 2017). 
As the academic literature on zombie firms is still emerging, there are no ex-ante assumptions on the research results; hence, instead of hypotheses, the goal here is to use longitudinal data that precede "becoming a zombie" state and identify the most important financial predictors of this state. Two main approaches are considered: logistic or probit regression, and discriminant analysis. Similar to Storz et al. (2017), we noticed that the literature on zombie companies had been particularly silent in European countries, so the analysis will focus on diverse European countries, such as Germany, Spain, Poland and the Czech Republic, to account for possible legal and cultural differences across countries. 
Table 1. Completed 2-page pitch template on Determinants of Becoming a Zombie Firm

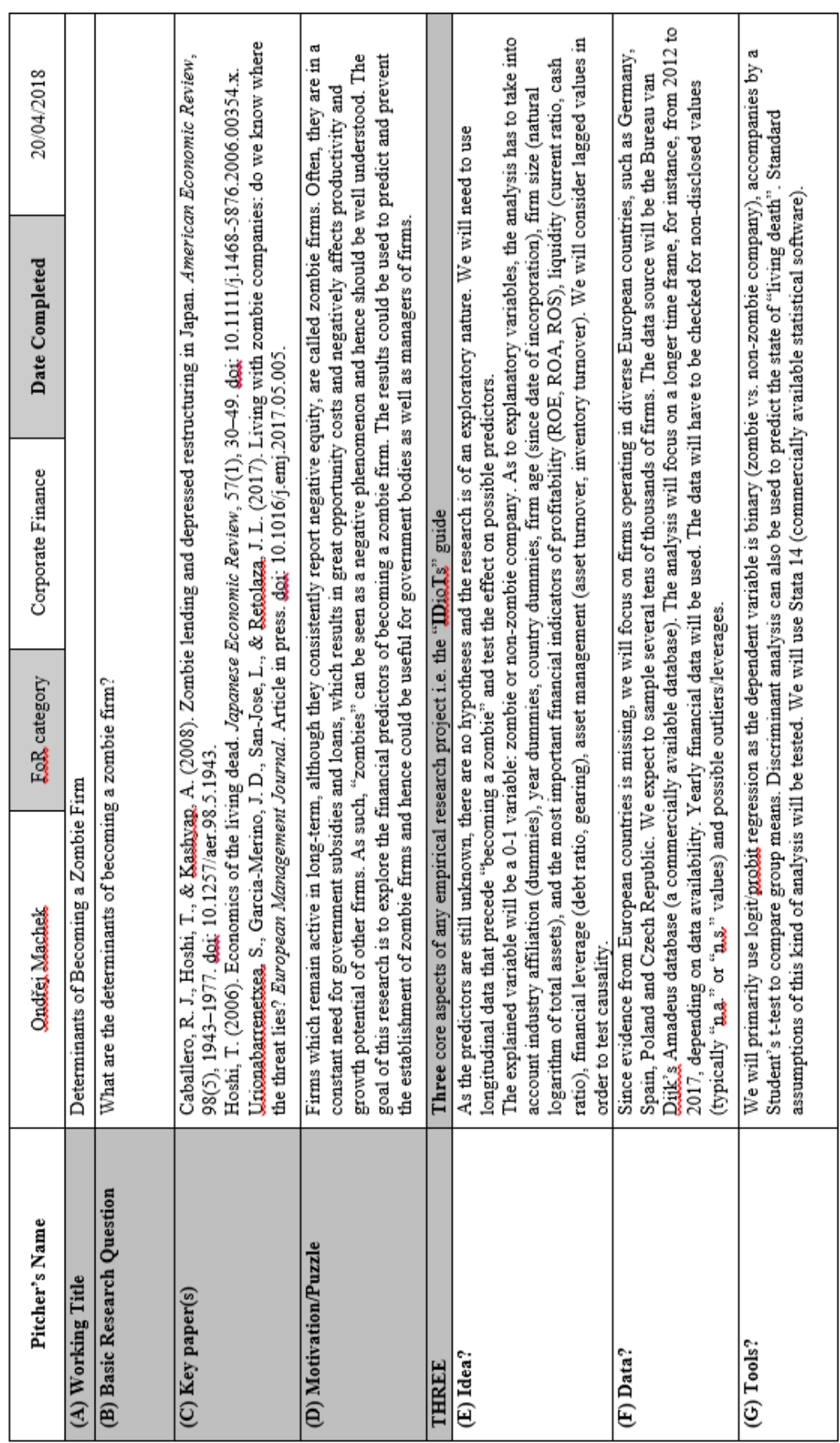




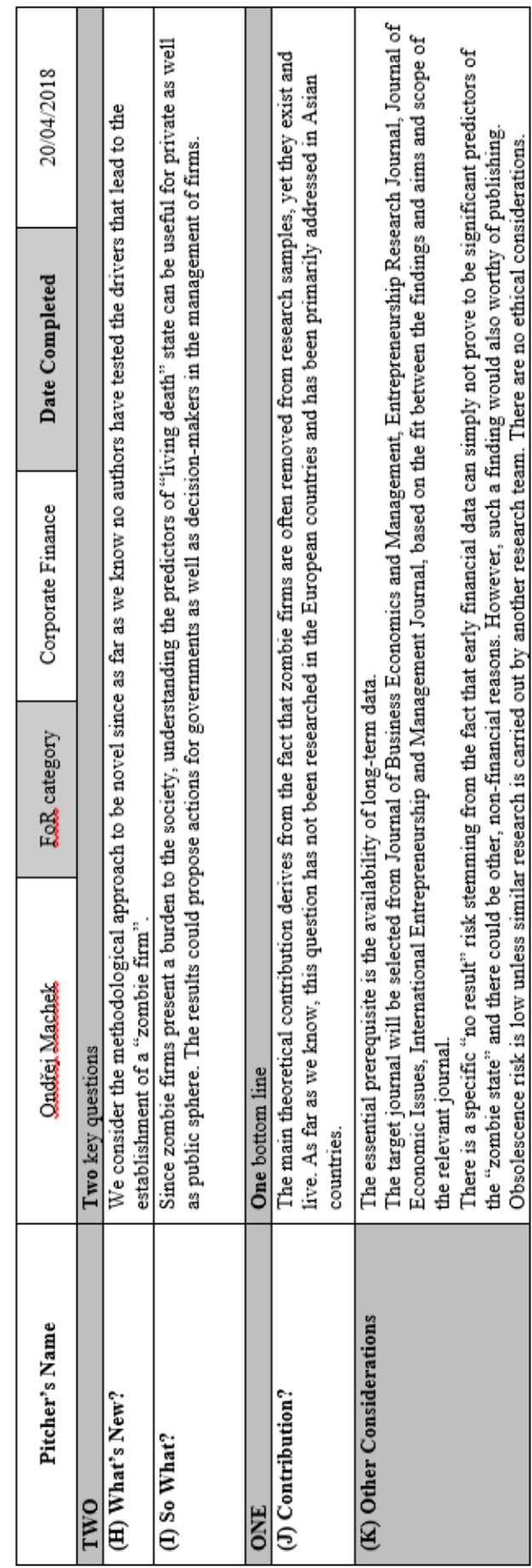

Vol. 17, No. 4 
Zombie companies present a burden to the society. They require long-term funding from governments, which results in great opportunity costs and negatively affects productivity and growth potential of other firms. Indeed, Caballero et al. (2008) found that "zombie-dominated industries exhibit more depressed job creation and destruction, and lower productivity".

However, zombie firms are often removed from research samples, yet they exist and live, and they are a rather sad part of the economic reality. Hoshi (2006) compared zombie firms with other firms and found out that zombies were less profitable, more indebted and more present in non-manufacturing industries. Hence, there is some evidence about the financial characteristics of zombie firms, but it is unknown whether it is possible to recognize this state early enough and possibly prevent it. Understanding the predictors of "living death" state can be useful for governments as well as decision-makers in the management of firms.

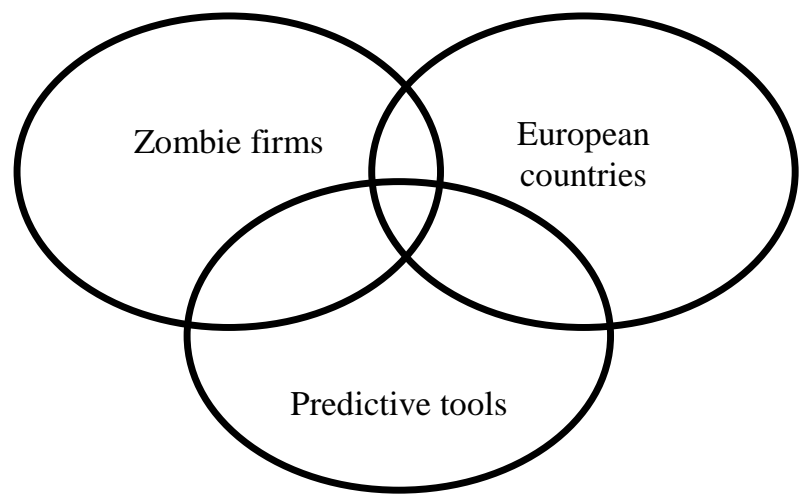

Figure 1. Mickey Mouse diagram characterizing novelty of research idea

The above discussion allows us to outline the Mickey Mouse diagram characterizing novelty of research idea (see Fig. 1) consisting of three circles: zombie firms (the main focus of the project), European countries (no evidence so far), and prediction (not addressed in the existing literature). The intersection of these three circles present, in our view, a research area worthy of further investigation.

\section{Personal Reflections on the Pitch Exercise}

We have first been made familiar with the pitching template during prof. Faff's lecture held on March 30, 2016, at the Faculty of Business Administration, University of Economics, Prague. Since then, it has been recommended to our Ph.D. students when presenting the plans for their doctoral dissertation projects. The template is also used by our academic staff (see e.g. Dvouletý, 2017). 
The initial pitch was completed within three days, and after further discussion with our colleagues from the Faculty of Business Administration, it took about one week to complete the pitching template. This relatively short time was due to an already existing idea about "what to do," the importance of the topic was clear to us, but the research plan was not well articulated.

The exercise has been quite useful in several ways. First, it allowed the author to elaborate a research plan for an initially rather superficial research idea. The pitching template forces the pitcher to proceed in a very systematic way from realizing the very basics to specifying the real contribution of the research idea. With a simple structure, the pitching template also allows for finding new ideas and then making modifications and gradually improving the research plan in a backand-forth way.

\section{Conclusion}

In this letter, we present the application of the Faff's $(2015,2017)$ pitching template for developing a research plan focused on the determinant of becoming a zombie form. The personal reflections on the pitch exercise will surely lead to our further recommendation of the pitching template to other research-involved colleagues at our home university, but also to Ph.D. students (for clarification and presentation of their research ideas) and even for Ph.D. applicants. Moreover, the template can also be used by the students of the Master's degree course "Research Methods" taught at the Faculty of Business Administration, University of Economics, Prague when elaborating and presenting their mandatory research projects.

\section{References}

Bridge, R. (2013) "Breathing new life into zombies", The Telegraph, 09 November 2013

Caballero, R. J., Hoshi, T. \& Kashyap, A. K. (2008) "Zombie lending and depressed restructuring in Japan", The American Economic Review, vol. 98, no. 5: 1943-1977

Dvouletý, O. (2017) "Determinants of Nordic entrepreneurship: A reverse engineered pitch", Accounting and Management Information Systems, vol. 16, no. 3: 420-426

Faff, R. W. (2015) "A simple template for pitching research", Accounting and Finance, vol. 55: 311-336

Faff, R. W. (2017) "Pitching Research®", available on-line at https://ssrn.com/abstract=2462059 or http://dx.doi.org/10.2139/ssrn.2462059

Hoshi, T. (2006) "Economics of the living dead", Japanese Economic Review, vol. 57 , no. 1: 30-49 
McGowan, M. A., Andrews, D. \& Millot, V. (2017) "The Walking Dead? Zombie Firms and Productivity Performance in OECD Countries". Paris: OECD Publishing

Stepek, J. (2008) "How zombie companies suck the life from an economy", MoneyWeek, 18 November 2008, available on-line at https://moneyweek. com/how-zombie-companies-suck-the-life-from-an-economy-14089/

Stothard, M. \& Giles, C. (2012) "Zombie companies stalk UK economy", Financial Times, 18 November 2012, available on-line at https://www.ft.com/content/d1 ecf0d0-316f-11e2-b68b-00144feabdc0

Storz, M., Koetter, M., Setzer, R. \& Westphal, A. (2017) "Do We Want These Two to Tango? On Zombie Firms and Stressed Banks in Europe", ECB Working Paper No. 2104, available on-line at https://ssrn.com/abstract=3052072

Urionabarrenetxea, S., San-Jose, L. \& Retolaza, J. L. (2016) "Negative equity companies in Europe: theory and evidence", Business: Theory and Practice, vol. 17: 307-316 